\title{
Community Geriatric Physiotherapy: Demand of Time, Demand for Active Ageing
}

\author{
Mohammed Zaglul Hai Russeel ${ }^{1}$, Md Monoarul Haque ${ }^{2 *}$ and Imran Islam Sumon Afrad ${ }^{3}$ \\ ${ }^{1}$ Consultant Physiotherapist, Uttara Crescent Hospital, Bangladesh
}

${ }^{2}$ Publication Secretary, Bangladesh Physical Therapy Association, Bangladesh

${ }^{3}$ Physiotherapist, Parul Physiotherapy Center, Bangladesh

Submission: January 31, 2018; Published: February 06, 2018

*Corresponding author: Md Monoarul Haque, Publication Secretary, Bangladesh Physical Therapy Association, Bangladesh, Email: monoarmunna@yahoo.com

\section{Editorial}

Physiotherapyis amodern, side-effectless, effective, evidencebased clinical practice guided, planned and implemented by physiotherapist independently in a scientific way to reduce and or cure burden of non-communicable diseases, acute and chronic musculoskeletal disorders, movement disorders, sport injuries, cardio-pulmonary rehabilitation, developmental disorders, neurological conditions etc. As geriatric population is increasing due to improvement of quality of life as well as access to health care services, musculoskeletal disorders are also increasing due to ageing process. Complain of muscle cramping, joint pain, fall, urinary incontinence, constipation, nutritional imbalance, behavioral change are usually seen in the later stage of life.

Physiotherapy has many specialties. Geriatric physiotherapy is one of them as a medical specialty. Effective implementation of physiotherapy can help aged people retain their independence, reduce or prevent long-term illness or just want to improve their general health as well as mobility or active life by gaining better strength and balance. When move to older age we usually prone to lose flexibility, strength and often balance but overcoming

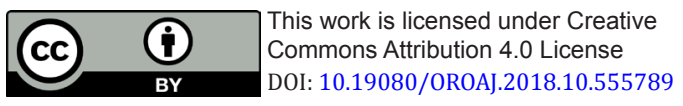

these problem is not so easy rather challenging. Loss of these functions could lead to a fall that could cause serious injury.

Physiotherapy is proven helpful to improve these functions. Osteoporotic condition is another matter of concern among seniors because it is a progressive bone disease characterized by a decrease in bone mass and density, can lead to an increased risk for fractures. Hip fracture is very common due to fall. Routine basis exercise protocol can help control the effects of this condition. As mentioned earlier arthritic pain disrupts old age group; we can alleviate symptoms of arthritis by providing strength training and modifying activity and life style specifically designed for them. Finally physiotherapy for geriatric people has a variety of benefits which can include not only gaining strength and balance, but also providing a renewed sense of confidence. Physical therapy can give seniors back their independence and make daily tasks easier. Physiotherapy should be reached at community level. Some Non-Government Organizations (NGOs) have taken nice initiative to provide physiotherapy services to root level i.e. union level. Bangladesh Physical Therapy Association is giving technical assistance in order to smooth running of the program.

\section{Your next submission with Juniper Publishers will reach you the below assets}

- Quality Editorial service

- Swift Peer Review

- Reprints availability

- E-prints Service

- Manuscript Podcast for convenient understanding

- Global attainment for your research

- Manuscript accessibility in different formats

( Pdf, E-pub, Full Text, Audio)

- Unceasing customer service

Track the below URL for one-step submission https://juniperpublishers.com/online-submission.php 